University of Rhode Island

DigitalCommons@URI

Open Access Master's Theses

1985

\title{
PUBLIC ACCESS CABLE TELEVISION AS A PLANNING TOOL
}

Mark Andrew Brady

University of Rhode Island

Follow this and additional works at: https://digitalcommons.uri.edu/theses

\section{Recommended Citation}

Brady, Mark Andrew, "PUBLIC ACCESS CABLE TELEVISION AS A PLANNING TOOL" (1985). Open Access Master's Theses. Paper 375.

https://digitalcommons.uri.edu/theses/375

This Thesis is brought to you for free and open access by DigitalCommons@URI. It has been accepted for inclusion in Open Access Master's Theses by an authorized administrator of DigitalCommons@URI. For more information, please contact digitalcommons-group@uri.edu. 
PUBLIC ACCESS CABLE TELEVISION

\author{
AS A \\ PLANNING TOOL \\ by \\ MARK ANDREW BRADY \\ A RESEARCH PROJECT SUBMITTED IN \\ PARTIAL FULFILLMENT OF THE REQUIREMENTS \\ FOR THE DEGREE OF MASTER OF \\ COMMUNITY PLANNING \\ UNIVERSITY OF RHODE ISLAND \\ 1985
}




\section{MASTER OF COMMUNITY PLANNING RESEARCH PROJECT \\ of}

MARR ANDREW BRADY

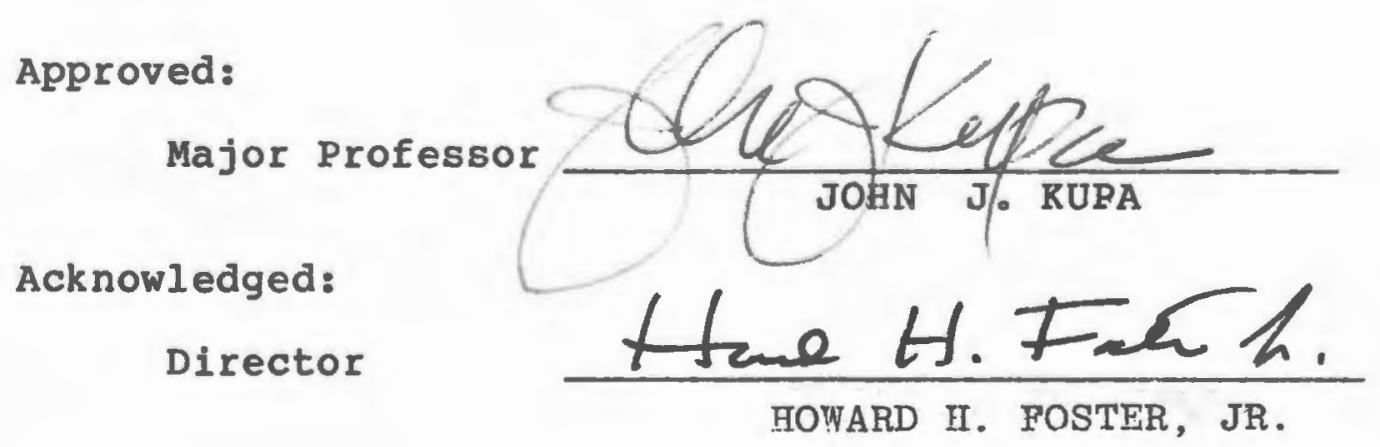




\section{ABSTRACT}

Historically public participation did not develop from some belief in democracy or duty but rather from unfulfilled needs, urban governments' failure to respond adequately to complaints of poor services. A direct response to this was the neighborhood movement.

Planning to one degree or another has been reactive, this study attemps to present to planners a new tool for reaching their community in a proactive educational manner. The initial phase of this study began with an examination of the legislative mandates governing cable companies. specificly the sections concerning public access airtime, technical assistance, and equipment availabilty. The second phase of this study involved the analysis of the perceptions of the cable company directors and planning professionals in relation to public access. A personally administered questionaire was used to determine such variables as: population parameters, levels of service, philosophy, misconceptions, levels of useage, and opinions. The results of this analysis suggest that the cable companies are committed to public access beyond the basic requirements of law. While each company varies in its method of assisting a group or individual, all take extreme care in assuring the best possible results. Planners for the most part are just discovering cable and while present utilization is low all, indications point to the recogniton by planners of the potential benefits of public access for 
serving their needs in reaching their community. 


\section{ACK NOWL EDGEMENT}

I wish to express my thanks to the faculty and staff of the University of Rhode Island for their patience and interest in my research.

Particularly I am most grateful to Dr. John Kupa, my major professor,for his enthusiasum and guidence and to professor Tim Tierney and Dr. Howard Foster for their assistance. Thanks are extended to Mary Lou Polumbo and Rollins Cable Company for their time and patience. A special thanks must go to my fiancee Nancy because with out her constant prodding this would not have been finished, and to my family for their translating.

Finally, I'd like to dedicate this to the memory of my father ... thanks dad for your sacrifices and your belief in me. 
PAGE

ABSTRACT,

ACKNOWLEDGEMENTS. • . . . . . . . . . . . . . . i i

TABLE OF CONTENTS . . . . . . . . . . . . . . i i

LIST OF MAPS. • • • . . . . . . . . . . . . . iv

LIST OF DIAGRAMS. • . . . . . . . . . . . . . iv

I. INTRODUCTION • • . . . . . . . . . . . . I I

Problem statement. . . . . . . . . I I

Scope of the study . . . . . . . . . 1

Hypothesis . . . . . . . . . . . 2

Assumptions. . . . . . . . . . . . 2

Research Methodology . . . . . . . . 2

Literature Review. . . . . . . . . 6

II. RESULTS. • • • • . . . . . . . . . 14

Methodology. . . . . . . . . . . 14

Findings . . . . . . . . . . . . . 16

III. CONCLUSION AND RECOMMENDATIONS . . . . . . 51

Findings . . . . . . . . . . . 51

Recommendations. . . . . . . . 52

Conclusion . . . . . . . . . . 55

APPENDIX I.-Cable Company Questionaire. • . 57

APPENDIX II.-PIanner Questionaire. . . . 60

FOOTNOTES. . . . . . . . . . . . . . . 63

BIBLIOGRAPHY . . . . . . . . . . . . 64 
PAGE

l. Study Area . . . . . . . . . . . . 3

2.Times Mirror Cable TV of Rhode Island . . . 21

3. Rollins Cable Vision . . . . . . . . 23

4.Westerly Cable . . . . . . . . . . 25

5. Cox Cable . . . . . . . . . . . 27

6.Full-Channel Television . . . . . . . 30

7. Cable TV of East Providence . . . . . . . 33

8.Vision Cable of Rhode Island . . . . . . 36

9. Rhode Island CATV Corporation . . . . . 39

10.Block Island Cable TV . . . . . . . . 41

1l.Rollins Cable, Bellevue, Newport . . . . . 43

12. Rollins Cable Vision of Rhode Island. . . . 45

\section{LIST OF DIAGRAMS}

l.Advertisement Local Organization Production . 18 2.Talent Release . . . . . . . . . . 57

\section{LIST OF TABLES}

1. Cable Companies Questionaire Response . • . 


\section{INTRODUCTION}

Historically, public participation did not develop from some belief in democracy or duty but rather from unfulfilled needs, urban governments failures to respond adequately to complaints of poor services. A direct response to this was the neighborhood movement. Planning to one degree or another has been reactive, present technology offers the opportunity to change this.

\section{PROBLEM STATEMENT}

The basic fabric of planning has been the acceptance of and demand for increased citizen participation in various, if not all, phases of progression yet less than $1 / 2$ of one percent of the general public attend planning issue meetings. It is the objective of this study to present to planners a new tool for reaching their communities in a pro-active educational manner that way lending more credibility to the value planning.

Scope of the study

The scope of this research project is limited both spacially and by subject matter. The study area researched is comprised of those communities in Rhode Island that are presently serviced by cable companies or those that are to immediately go "on line". They are North Smithfeild, Woonsocket, Cumberland, Smithfield, Lincoln, Central Falls, Pawtucket, North Providence, Johnston, Providence, Cranston, East Providence, Warwick, Coventry, East 
Greenwich, North Kingstown, South Kingstown, Narragansett, Hopkinton, Westerly, Tiverton, Portsmouth, Middletown, Newport, Little Compton. (map \#1)

\section{HYPOTHESIS}

As mentioned, it has become accepted that public participation is an important element of the planning process. But, present methods of stimulating this participation have shown little success.

It is the contention of this research project that the utilization of public access cable by planners can strengthen the planners credibility on a given issue by presenting information to the community by means of a direct access medium. The planner then has a better chance of setting some or all of the record straight and revealing that possibility that only half of what is said is printed or is somehow misconstrued.

\section{ASSUMPTIONS}

The study area presents a valid representation of the attitudes, usage patterns, and potential for planning usage of public access cable for the state as a whole.

\section{RESEARCH METHODOLOGY}

The research design addressed the problem statement, scope of the study, and assumption, literature review and the significance of the study is in this section. The 


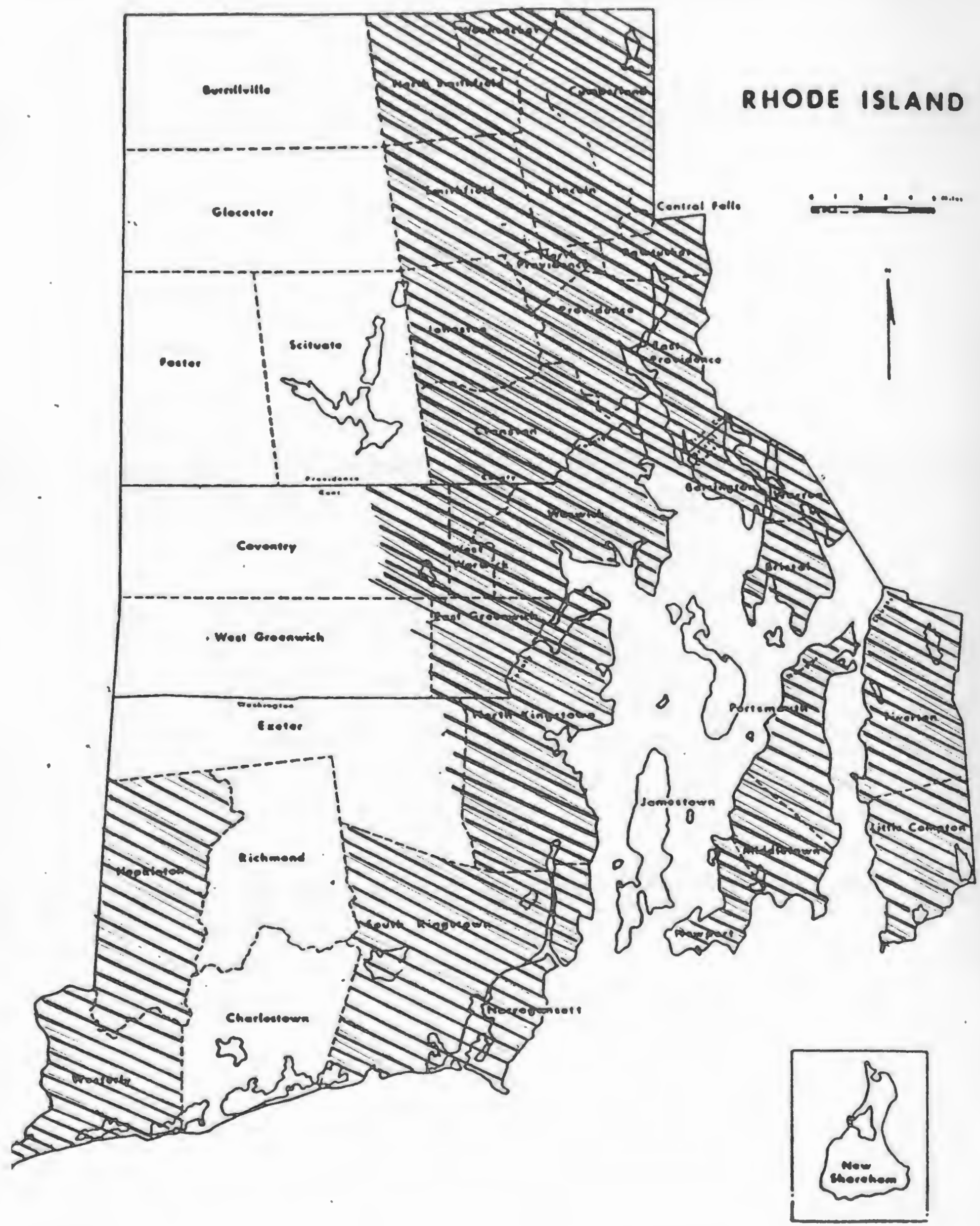


potential usage of public access cable is rooted in the legal requirements recorded by the Federal and state laws governing Community Antenna Television Systems. An assessment must be made of the willingness of the individual cable operators to either simply meet these requirements or to actually promote public utilization of the airwaves. Cable operators represent only half of the participants. Planners must be canvassed to obtain a full measure of the systems impact of said use, not merely its potential impact.

To assess the present levels of perception of public access validity, a questionaire was designed and presented to the cable operators servicing the study area. The research design was incorporated into the questionaire to; 1) population parameters, both present and potential 2) levels of service and bureaucracy 3) companies philosophy and attitude in relation to public access commitment 4) general misconceptions perceived and estimated which have occurred in the public access realm.

The questionaire was personally administered,by phone, to the General Managers of the companies operating in the study area. This included Rollins Cable Vision of Rhode Island, Rhode Island CATV Corp., Cox Cable Cranston/Johnston Inc., Rollins Cable Vision, Westerly Cable TV Inc., Vision Cable Co. of Rhode Island, Cable TV of East Providence, Block Island Cable TV Inc., FullChannel Television Inc., Times Mirror Cable TV of Rhode 
Island, Rollins Cable Vision (Bellevue-Newport).

The attempt was to get $100 \%$ response but time restraints required that a systematic method be implemented that would assure maximum response within a logical time frame. Multiple calls (15 maximum) were placed to each company. If the company's spokesperson could not be reached by the 15th attempt the response was considered non-attainable. The phone calls were administered over a two week period.

A total of eleven of the thirteen companies responded representing an 84.68 response level. In gaining knowledge of the cable companies position and requirements it was necessary to obtain insight as to the planners' positions since they would be the proposed users. Again the research design was incorporated in the development of the survey format. Areas of concentration

would be 1) population, both present town population and average planning meeting attendance 2) levels of usage, both present and future 3) the perception of cable in planning.

The questionaire was personally administered, by phone, to city and town planners in the study area. If a community did not have a planning department questions were referred to the planning authority or planning board chairperson, whichever was appropriate.

As with the cable companies the goal was for a $100 \%$ response rate but this was neither practical nor feasible. 
Again, the 15 phone call attempt limit was imposed and the calls were made over a three week period to accommodate the size of the survey population.

A total of 30 communities were canvassed with 17 replies; amounting to a 56.67 response rate.

\section{LITERATURE REVIEW}

Publications in this field are limited, if not, scarce. The Ninety-Eighth Congress of the United States meeting on January 23, 1984 undertook to amend the Communications Act of 1934 to provide a national policy regarding cable television.

Known as the Cable Communications Policy Act of 1984, its purpose: was 1) " establish a national policy concerning cable communications" 2) "establish franchise procedures and standards which encourage the growth and development of cable systems and which assure that cable systems are responsive to the needs and interests of the local community" 3) "establish quidelines for the exercise of Federal, State, and Local authority with respect to the requlation of cable systems" 4) assure that cable communications provide and are encouraged to provide the widest possible diversity of information sources and services to the public" 5) "establish an orderly process for franchise renewal which protects cable operators against unfair denials of renewal where the operator's past performance and proposal for future performance meet the 
1

stancards established by this title" 6) promote competition in cable communications and minimize unnecessary regulation that would impose an undue economic burden on cable systems."

The Legislature to assure that ,"... the widest possible diversity of information sources and services..." are supplied to the public, passed S.66-4 Part II- Use of Cable Channels and Cable Ownership restrictions. Section 6lla which states "A franchising authority may establish requirements in a franchise with respect to the designation or use of channel capacity for public, educational,or governmental...". Section b "A franchising authority may in its request for proposals required as part of a franchise, and may require as part of a cable operator's proposal for a franchise renewal, subject to Section 626, that channel capacity be designed for public, educational, or governmental use, and channel capacity on institutional networks be designed for educational or governmental use, and may require rules and procedures for the use of the channel capacity designated pursuant to this section." 4

To ensure that the economic burden of equipment or the lack of technical knowledge did not restrict an individuals or groups' ability to gain access to the system and in turn prohibit the airing of their program section c reads " A franchising authority may enforce any requirement in any franchising regarding the providing or use of such channel capacity. Such enforcement authority includes the authority 
to enforce any provisions of the franchise for services, facilities, or equipment proposed by the cable operator which relate to public, educational, or governmental use of channel capacity, whether or not required by the franchising authority pursuant to subsection (b)."

The enabling legislation as written focused on the franchising authority, the act refers to any governmental entity empowered by Federal, state, or Local law to grant a franchise. This authority, in Rhode Island, has come to rest with the Public Utilities Commission Division of Public Utilities and Carriers. The Rules Governing Community Antenna Television Systems was adopted on January 30,1981 and revised to January 17,1983. "These rules and regulations are promulgated in accordance with the authority granted to the Division of Public utilities and Carriers by sections 39-19-2 and 39-19-6 of the Rhode Island General Laws, as amended, to supervise and regulate every company owning or operating a community antenna television plant within this staten. Title 39, Chapter 19 sets terms that "...every person or company owning or operating a CATV system in the state is subject to the jurisdiction of the Division,to these rules, and to such orders as the Division may issue." 8

The Public Utilities Commission has made specific provisions that insure that the original intent of the Federal statute, providing for public access, is not lost. Initial stage of franchise development requires the 
application for a

Compliance order certificate. This document is necessary and if "any deficiencies remained" they must be fully resolved before one is assigned a docket number for an administrative 10 hearing.

A provision on page 15 sub. sec.(v.) requires "the number of channels to be made available for access and institutional uses; the facilities, equipment, and staff to be made available for such uses, and a schedule of charges for facilities, personnel, and utilization of such channels and services (such schedule of charges shall be included in the proposed tariff)". "More specifically chapter 14 page 46 sec 14.1 of Rules Governing Community Antenna Telivision Systems state 1) "public access channels shall be made available for use by members of the general public on a first-come, first-serve nondiscriminatory basis. The VHF spectrum shall be used for at least one of the channels; 3) Government access channels shall be made available for use by municipal and state government". The rules require that these channels, a minimum of one (1), be made available immediately upon the commencement of the subscribers' service. Additional public access chanels is based on the number of television channels the station has operating and the demand for the access time.

Section $14.1(\mathrm{~g})$ sets parameters for studio access by public in conjunction with their productions. "Any fixed studio provided pursuant to these rules shall be made 
available without charge to the users of the specially designated access channels. The CATV system operator shall grant such users reasonable access to the studio facilities during normal business hours. In addition, access to the studio facilities shall be granted upon request until $9 \mathrm{pm}$ weekday evenings and at least four (4) hours per day on weekends." 13

Where as, most points of production originate outside the studio sec. 14.3 sets explicit specification for portable production equipment capacities by the franchise. " Within six (6) months of commencement of service, each CATV system operator shall provide mobile and/or portable television production equipment for use by residents of that service area in the production of programming for specially designated access channels. Such equipment shall be maintained by the system operator, and shall be available from one or more convenient and accessible locations within the service area." "(b) Each CATV operator shall provide portable equipment of a type and in quantities adequate to satisfy the program production needs of the users of specially designated access channels in that service area. At a minimum, however, each CATV systems operator shall immediately provide two (2) complete sets of the following equipment: 1) one (1) portable color video camera, equipped with zoom lens, tripod, dolly, AC power supply and batteries; 2) one (1) portable color video tape recorder, using a format in common use in the cable 
telivision industry; 3) one (1) portable lighting kit; 4)

two (2) hand-held microphones suitable for outdoor use; 5) appropriate accessories, including but not limited to cords, cables, microphone desk stands, and an equipment cart." To extend that equipment maintained at the fixed studio is portable and not in use for the program production for specially designated access channels at that location, such equipment may be made available for use outside the studio."

To merely provide time and equipment would not provide the majority of users with the basic element to make the production actually materialize. This essential ingredient is the know how to use the cameras, troubleshoot, and eventually, edit the final copy. Section $19.4^{16}$ of the $\underline{\text { Rules }}$ Governing Community Antenna Telivision System addresses the need of personal and technical assistance. "(a) each CATV system operator shall make available an adequate number of appropriate programming and technical personnel to maintain and oversee the use of the production equipment required to be provided by this chapter, and to provide the following training and technical assistance." 17 "(1) training of government employees, employees of educational institutions, and representatives of non-profit community organizations and institutions in the use of system production equipment available for access and institutional program production.

(2) training of the public in the use of system production equipment available for public access program production. 18 (3) guidance and planning assistance to government 
officials, officials of educational institutions, and officials of non-profit community institutions and organizations in the development of access programming and institutional services, and the design and the utilization of facilities for production, origination, and internal distribution (i.e., within bujldings)." 19

"(a) each CATV system operator shall employ at least one (1) full-time coordinator of access and institutional services, who shall have continuing oversight and administration of the development and utilization of access programming and institutional services."

"(b) and all technical, planning, and instructional assistance provided by a CATV system operator pursuant to this section shall be provided at no expense to the access services user." 21

Many argue that public participation is only as good as the participants and that a new tool, public access, will do little to stimulate additional participation because the public does not watch public access.

Fortunately, a number of recent surveys offer documentation which support the belief that there is a genuine willingness amongst many traditional television viewers to accept alternative viewing.

For instance, in April of 1982 the ELRA Group, a national cable research company published a study called, Cable Mark. The study covered areas of the country where major franchise awards had been achieved in the past 
24 months. The researchers asked repondents to rank their interest in 18 different program types. Amongst these 18, public access ranked as one of the top 5 choices. Specifically, 638 of the respondents indicated an interest in public access programming. This rating placed it above such catagories as cultural programming and sports.

In 1979, Michigan State University's Department of Telecommunications obtained a grant to conduct a study of local cable subscribers and access users in East Lansing, Michigan, where there has been access programing for nearly 10 years. An important part of the study, which was conducted through telephone surveys and personal interviews, concerned viewership of public access programs. Those surveyed were asked such questions as, "Do you view public access programming?", "If so,how frequently do you view and which programs do you prefer?". Other questions concerned the quality of the access channels picture quality. The results indicated that approximately 748 percent of the cable subscribers were aware of the access channel, and that approximately 538 percent watched on a regular basis.

Thus, it appears that the viewing public with a little exposure is willing to accept "alternative-to-broadcaststylen television programming.

The National Federation of Local Cable Programmers in Washington D.C. was contacted in reference to national 
activities of planners utilizing public access cable. The Federation has an information service but nothing directly related to this study at hand.

A search was also conducted to determine the coverage of this type of activity by the American Planning Association Journal. While some articles made reference to cable and public access none served the needs of this author.

The emphasis on journal search stemmed mainly from the relative infancy of the field. A text and non-fiction book search proved fruitless. In some sections of this text reference to recent publications is made. These were "how to" books and lent little foundation information.

\section{RESULTS}

\section{METHODOLOGY}

A questionaire was specifically tailored to access as much essential information as possible from the two parties targeted, the first being the cable companies, the second being the planning authorities. Again, both groups were limited to the area presently or immediately serviced by cable.

The questionaire used in the survey at the cable companies consisted of 13 questions. The questionaire was personally administered by phone and took from 30 to 60 minutes. Most of the questions were open ended, none 
offered a selection of answers so as not to prejudiced answers of those interviewed. A copy of the questionaire is found in Appendex I. Results of the actual surveys may be found in Appendex II. The findings were broken down and presented in two modes. The first is an index of cable companies, by geographic coverage, and the level of service they offer. Also, comments on the bureaucratic demands of the companies (ie Paper work needed to fill out, deadlines). This is not presented as an endorsement of one company over another. It is meant as a reference to planners in that area as to the requirements they must meet to air a program and what technical assistance they can expect.

General findings are presented as to misconceptions regarding public access and the degree to which the planning field has taken advantage of the services.

The questionaire administered to the planning authorities consisted of 13 questions. The questions were administerd by phone, and lasted between 45 minutes to an hour and a half. The questions were left open ended to get as much information as possible and to give the planners the benefit of full expression on, what was, for most, a new subject. A copy of the questionaire is found in Appendex II.

Representatives for the cable system companies fell in two groups. The first were general managers of the stations and comprised 758 of the responses; the remaining 
258 were directors of public access programming for the stations.

Professional planners made up 82.38 of those responding to the planning questionaire. Responses from nonprofessional, planning Board Chairperson, were 17.68 of the total.

FINDINGS

CABLE COMPANIES QUESTIONAIRE RESPONSE

The first question asked the cable company representitives was "What is the number of households you now service?" The second question asked was "What is your approximate household potential audience?" These questions sought to establish both present and future residence that might be reached by airing a program on the public access. The present households serviced by the companies totals 127,348 with an average of 18,192 households per company. The projected potential totals 269,275 households, this averages to 38,467 households per company.

Based on 1980 census data the total number of house hold in the study area is 301,066 revealing that at present the cable companies are reaching 438 of the household in the study area and that potenially 898 may be reached in the near future.

The question, "What are the most common misconceptions that are made in reference to public access?", was asked of the respondents. The reply was unanimous, "it is easy to make a production." Not that the process itself is 
difficult, but rather, the amount of time consumed developing the program concept, filming the program and the time involved in finishing the product to be aired. One respondant stated, "Most people do not realize the amount of time involved in doing a production, you do not just film and throw it on the air. Post and Pre production time is consuming." It was pointed out that, "Production time is based on the sophistication of the project". The more sophisticated or "Slick" a product is intended to be the more time is involved in the preproduction aspects of: planning (identifying needs, audience, content writing objectives), design (visualization of concepts) and the production functions of (assembling and editing). The suggestion was made that "with the volume of time involved in the product, it should be done by a team". This would reduce the amount of time any one individual would have to contribute and also increase overall efficiency by having various stages in operation at once.

The next most frequent response was that people believe the cable companies do all the work. The cable companies produce what is referred to as "Local Organization Production". These are programs that the company produces for local airing. They are not required to produce public access programs. They do however, utilize subject matter brought forth by groups or individuals. An example is the public affairs conference aired by Rollins Cablevision, and co-sponsored by Brown University and the Providence Journal. 


\section{CABLE TELEVISION STATEWIDE MICROWAVE INTERCONNECT Q.ST I S. C AMERICA'S HEALTH CARE DILEMMA}

This public affairs conference, co-sponsored by the Providence Journol. Bulletin and Brown University, will be presented in Sayles Hall on the Brown University Compus, March 11, 12 and 13, with lectures and discussions at 12 noon, 4 p.m. and 8 p.m., each day. These sessions ore free and open to the public. The Cable Television Statewide Microwave Interconnect urges you to alfend these sessions in person.

MONDAY, MARCH 11 (af Sayles Hall)

'NOON COSTS AND CAUSES: AN ECONOMIST'S VIEWPOINT (SESSION I)

4 P.M. HARD CHOICES: WHO LIVES, HOW, AND WHO DECIDES? (SESSION 2)

8 P.M. HEALTH AND LIFESTYLE (SESSION 3)

TUESDAY, MARCH 12 (at Sayles Hall)

NOON ACCESS TO CARE: WHERE ARE THE HOLES IN THE NET? (SESSION 4)

4 P.M. HEALTH CARE AND THE ELDERLY

(SESSION 5)

8 P.M. THE HEALTH COST OF DOING BUSINESS

(SESSION 6)

WEDNESDAY, MARCH 13 (at Sayles Hall)

- TOON THE PROPER ROLE OF GOVERNMENT

(SESSION 7)

4 P.M. A SAMPLING OF ALTERNATIVE HEALTH PROVIDERS

(SESSION 8)

8 P.M. COST VS. CARE: AMERICA'S HEALTH CARE DILEMMA (SESSION 9) WRONGLY CONSIDERED

PART 1: THE AMERICAN CRITIQUE

PART 2: THE CANADIAN EXAMPLE

BUT IF YOU MISS A SESSION, YOU CAN STILL SEE IT ON CABLE! MARCH $I 1$ (CABLECAST)

2:00 P.M.-3:30 P.M. SESSION 1; 8:00 P.M.-9:30 P.M. SESSION 2; 9:30 P.M. SESSION 3; MARCH 12 (CABLECAST)

2:00 P.M.-3:30 P.M. SESSION 4; 8:00 P.M.-9:30 P.M. SESSION 5; 9:30 P.M. SESSION 6; MARCH 13 (CABLECAST)

2:00 P.M.-3:30 P.M. SESSION 7: 8:00 P.M.-9:30 P.M. SESSION 8; 9:30 P.M. SESSION 9

RHODE ISLAND CATV-Channel 47 COX CABLE-Channel 51

TIMES-MIRROR Cable-Channel 9

ROLLINS CABLEVISION-Channel 2 VISION CABLE-Channel 47

E. PROVIDENCE CABLE-Channel 16 FULL CHANNEL CABLE-Channel 9 WESTERLY CABLE will present this series one session a weck, at 6:30 p.m. Tuesdays, starting March 19th, on Access Channel 13.

BLOCK ISLAND CABLE will present this series storting Saturday, March 16 th, on Access Channel 5 (time to be onnounced on Channel 5).

A ROLLINS CABLEVISION

inńa nniniaintingi nonniprinat
DIVISION OF PUBLIC UTILITIES

STATE OF RHODE ISLAND

EOWARO D. DIPRETE, GOVERNOR 
The question, "What is your company's policy in reference to public access cable?" was asked in an attempt to gain some insight into the company's philisophical perception of public access and their committment to the program. Only 2 answered with reference to the PUC guidelines. The majority took a more positive stand. "Basically open door ... we accept all kinds [programs] from all areas in the state." "We encourage it [public access]." "We believe in public access." It was generally expressed by the company spokesperson that, "Public access is good for the communities." But the same person stated, "... companies are pushing ... people are not taking advantage."

In the questionaire presented to the cable system operators the results from question 4, "What kind of technical assistance do you offer?", question 5, "How would a planner get a production aired?", question 7, "What kind of notice should be given your company before air time?", question 8, "What time slots are available for public access?", question 9, "What would a planner need to know in order to successfully air a program?", and question 10,"Are there limitations as to what can be aired?" have been blended to develop the following profiles of the various companies. They are presented by Geographic Jurisdiction in the state.

Again, this is presented as a guide for the planner that may be interested in public access, but does not know 
the particulars expected by the company in his or her region. Their are policies common to all companies, specifically those that govern the airing of pornographic materials or programming of a profit generating nature. No programs will be aired on the public access system that is pornographic or are games of chance, lottery, or programs containing commercials. 


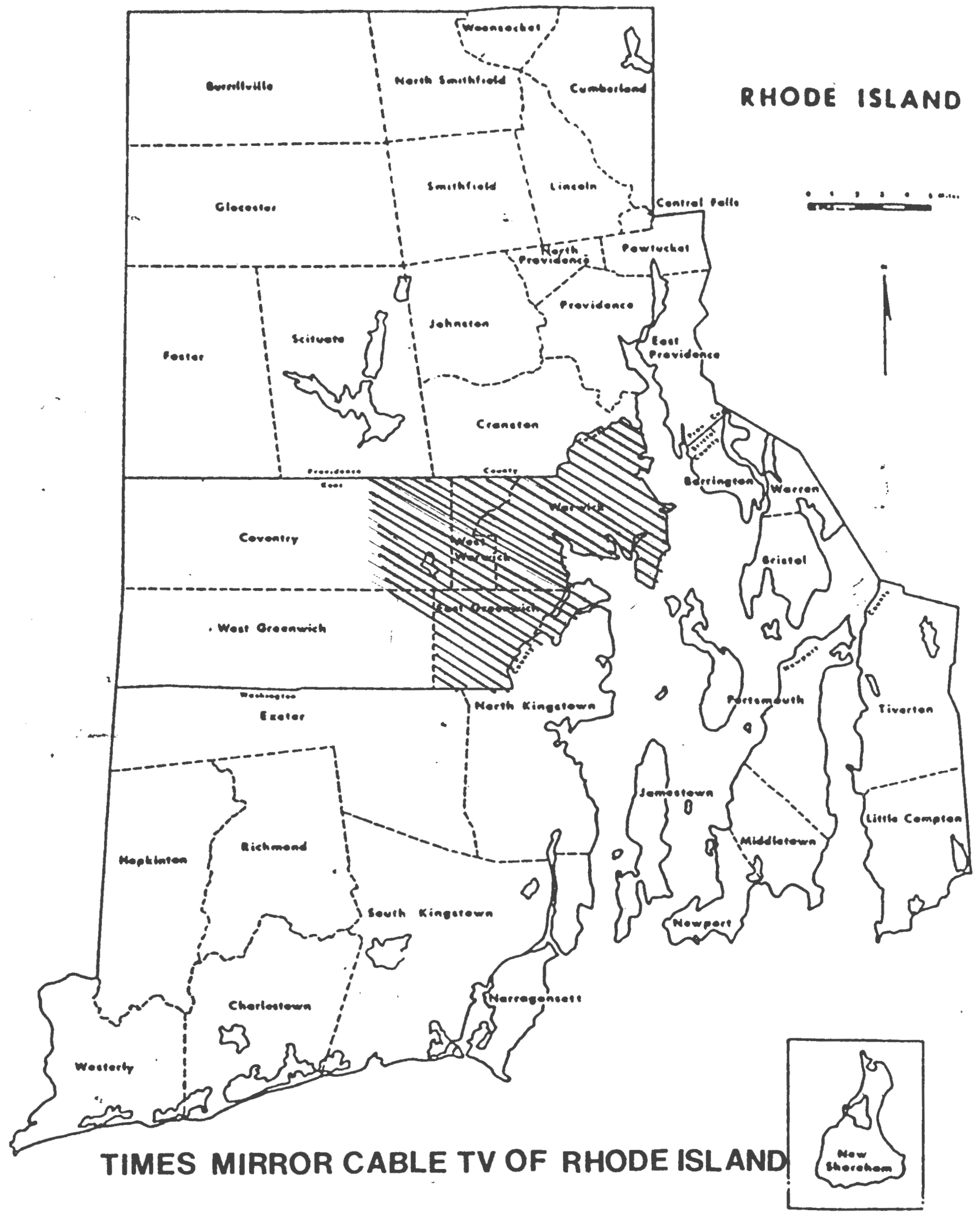




\section{WARWICK, WEST WARWICK, COVENTRY, EAST GREENWICH}

Times Mirror Cable TV of Rhode Island

West Warwick, Rhode Island

NO RESPONSE 


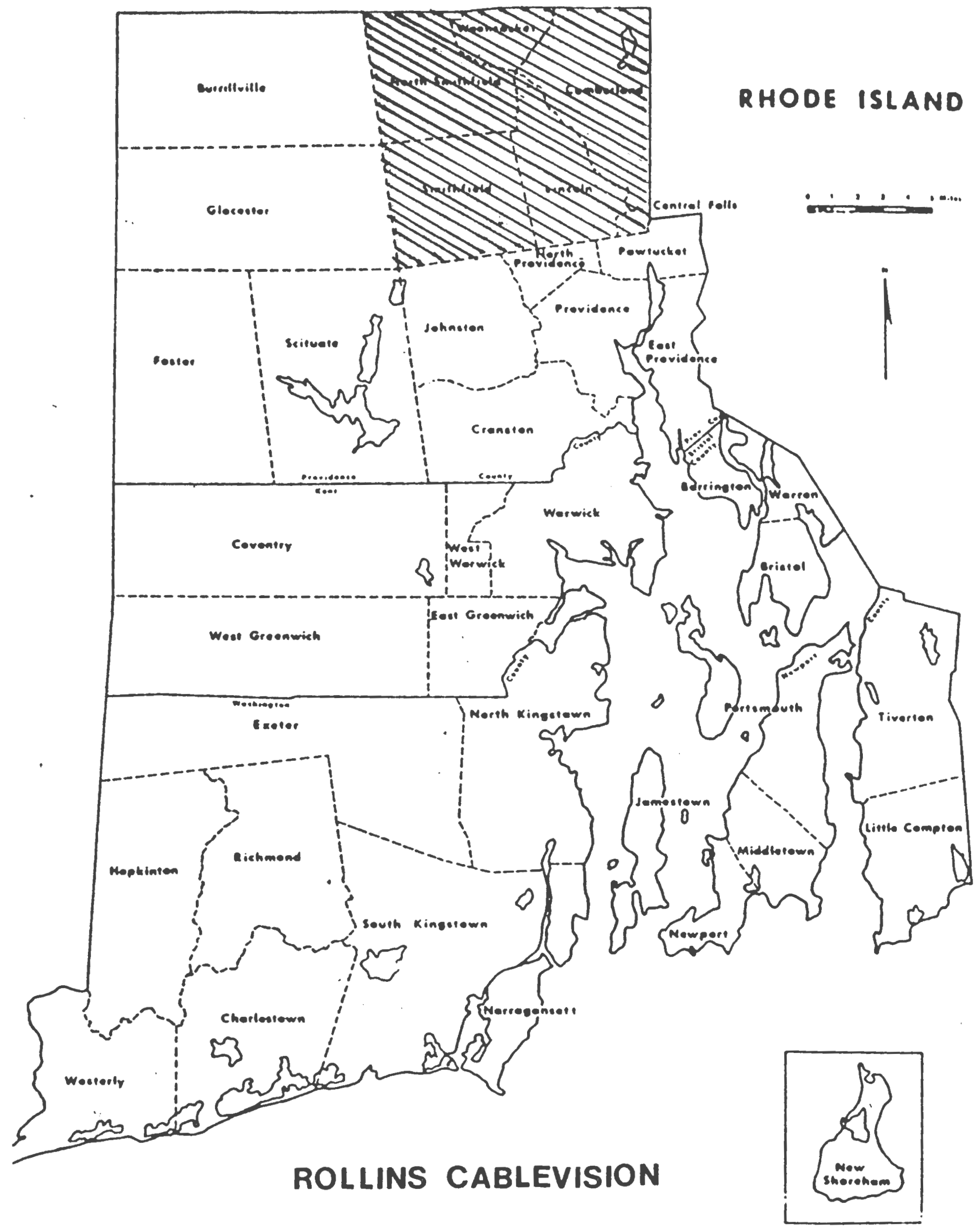


NORTH KINGSTOWN, SOUTH KINGSTOWN, NARRAGANSETT

\author{
ROLLINS CABLEVISION \\ NORTH KINGSTOWN, RHODE ISLAND
}

\begin{abstract}
Rollins provides a basic introductory class to familiarize the user with the camera equipment, recorders and microphones. They also give advice on trouble shooting various problems. Advance training is given on a one-toone basis. This is done for two reasons, practicality and effectiveness; many people take the first introductory class but there is a high attrition rate as the classes progress, and it proves more effective to offer a hands on situation when working with an individual or small group.

All equipment is available after you have been checked out on it. The studio facilities and all camera and editing equipment may be used; both can be reserved done so on a space available basis.

The public access director should be contacted at least 2 weeks prior to the airing of a program. He will assist in a matters pertaining to the airing including the completion of any paperwork and offer audio/visual quality review.
\end{abstract}

If the audio/visual quality is not acceptable the program requires reworking before it is aired. 


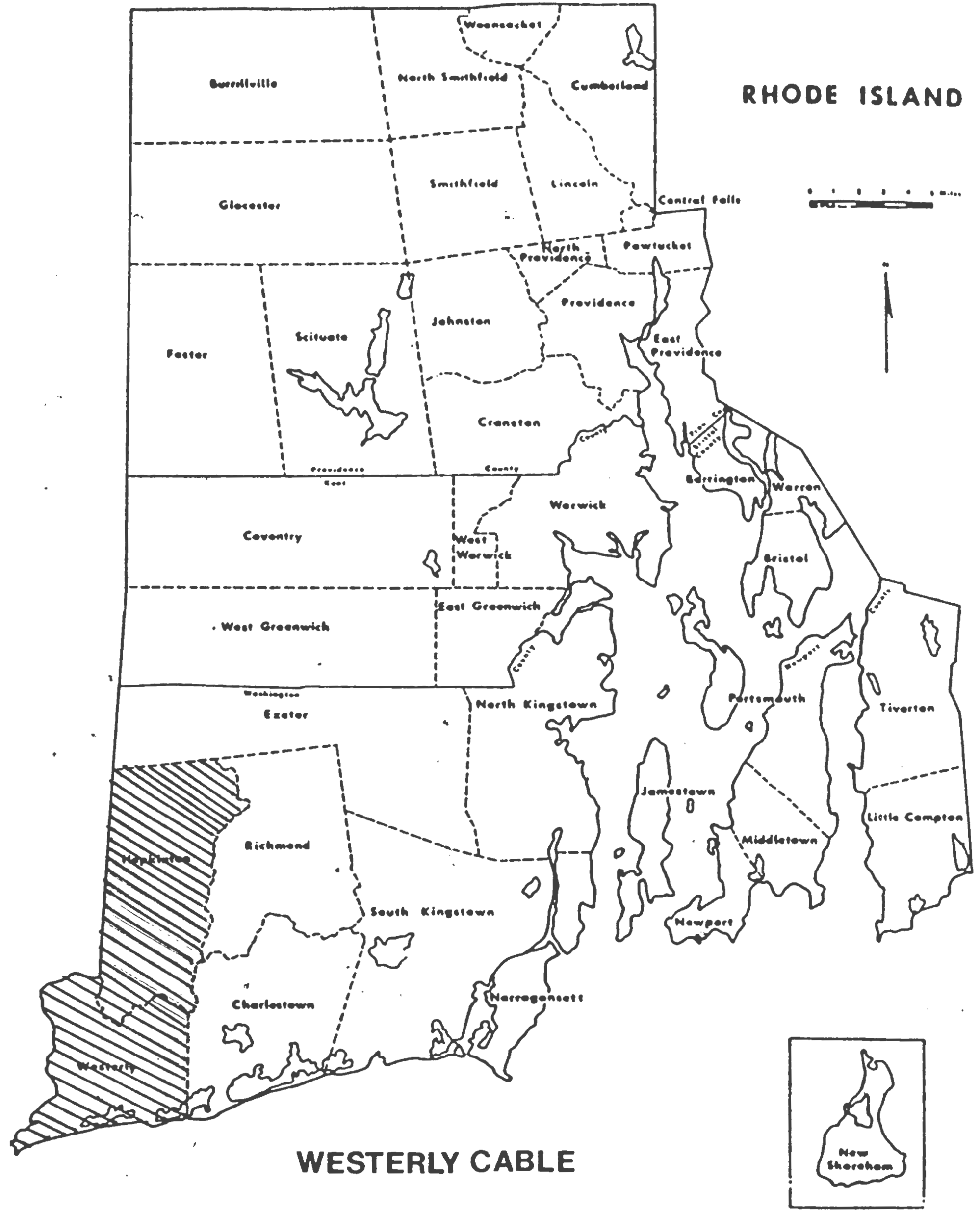




\section{HOPK INTON， WESTERLY}

Westerly Cable

Westerly, Rhode Island

NO RESPONSE 


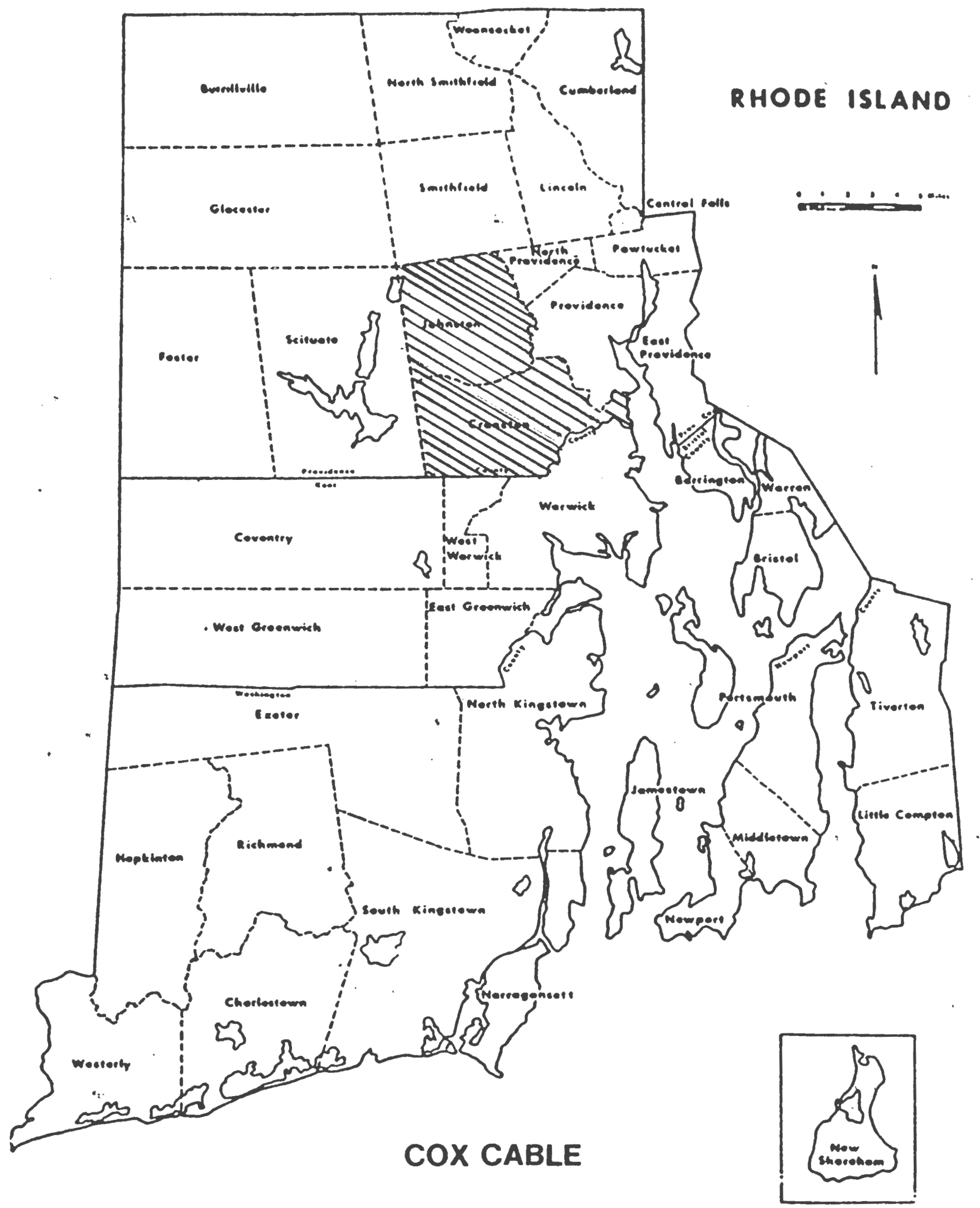




\section{JOHNSTON, CRANSTON \\ Cox Cable \\ Cranston, Rhode Island}

Cox Cable provides classes that vary by the level of expertise of those utilizing the services. They will tailor training to the needs of the organization involved.

Technical assistance is provided when needed, but training stresses areas that would provide some degree of expertise to allow for self satisfaction.

Equipment both in studio and take out are available, the only restriction mentioned was the prerequisite of having taken the classes and that equipment is on a first come first serve basis.

Cox Cable has a feature where they network their class graduates if technical assistance or additional personnel is needed for a project. They also survey to determine needs.

Airing a production on Cox Cable would require some paperwork and you have to have taken the classes. The paperwork is basic and covers areas of copyrights (print or music). They have a library of music copyrighted and talent releases. A description of this project is also required.

Cox's encourages at least one week's notice on a program. This allows time to arrange for airing slots and listing on 
public access programming board. Time slots are readily available, the recommended slots are between $6 \mathrm{p} . \mathrm{m}$. and $8 \mathrm{p} . \mathrm{m}$. so as not to compete with the major networks. 


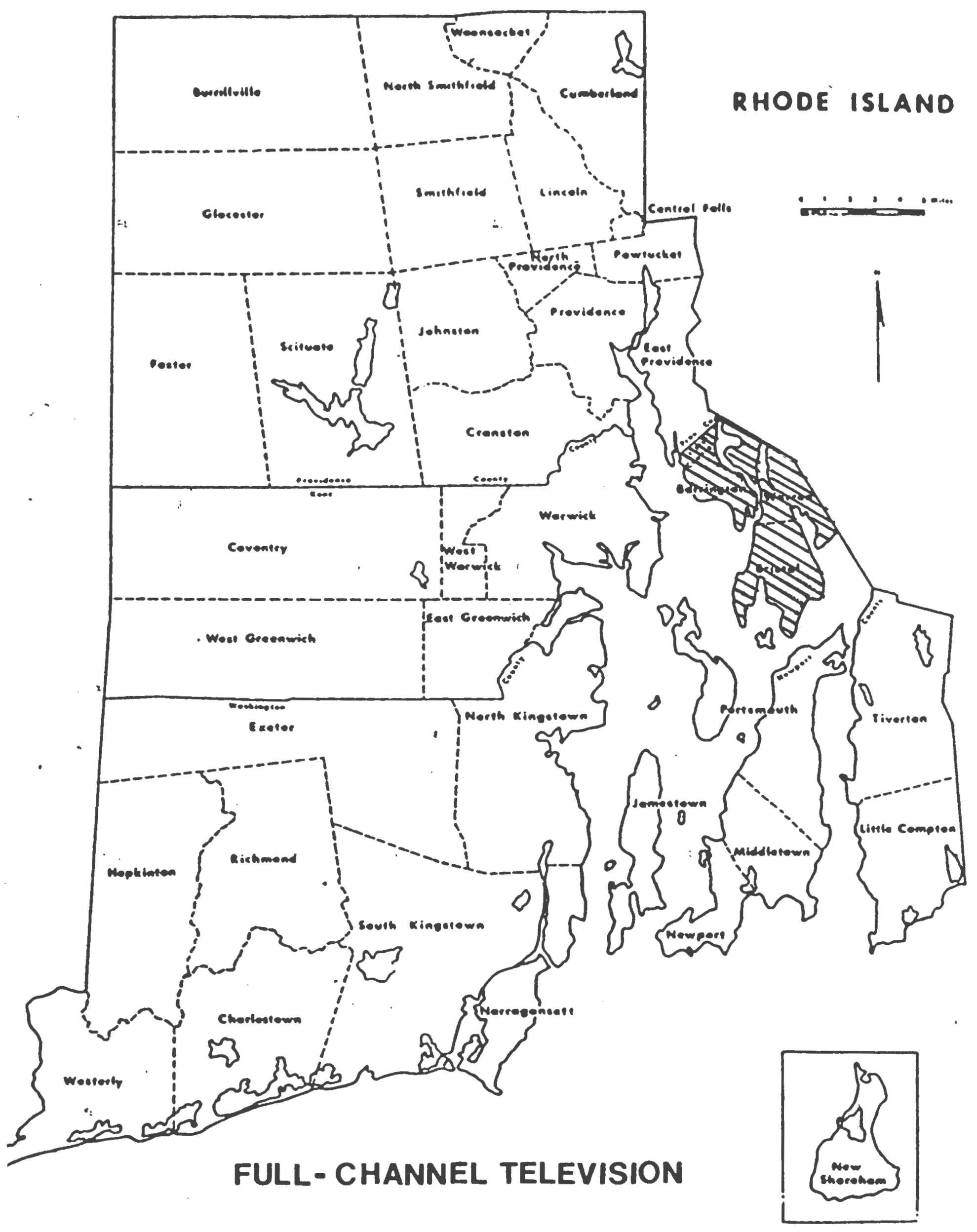




\section{BARRINGTON, WARREN, BRISTOL \\ Full-Channel Television, Inc \\ Warren, Rhode Island}

Full channels' services are limited to those members of the Bristol County Committee. Their training class service is a basic introduction to the equipment. Their second level training deals with editing and their students are required to log seven (7) hours of editing time.

Technical assistance is available to the extent that they will go to the shoot and assist where needed.

Equipment has a first come first serve insurance policy and is only available if you have taken the classes. An added restriction is that you cannot sign up for the equipment more than a month in advance to insure that the equipment is not monopolized by a few individuals.

Two weeks before anticipated air time a request form must be filled out to ensure no copywriters have been infringea upon. The tape of your program, if not live, must be at the station at least 24 hours before the scheduled air time. The program will be listed on the local access bulletin board.

The majority of requests for showing programs has been for prime time $7 p \cdot m \cdot-9$ p.m..The suggested time is between 7 and $8 \mathrm{p} . \mathrm{m}$. competing against game shows. But for the most part time slots are wide open. Company policy is not to air programs that lack technical quality. The two week advance 
helps give time to correct problems. 


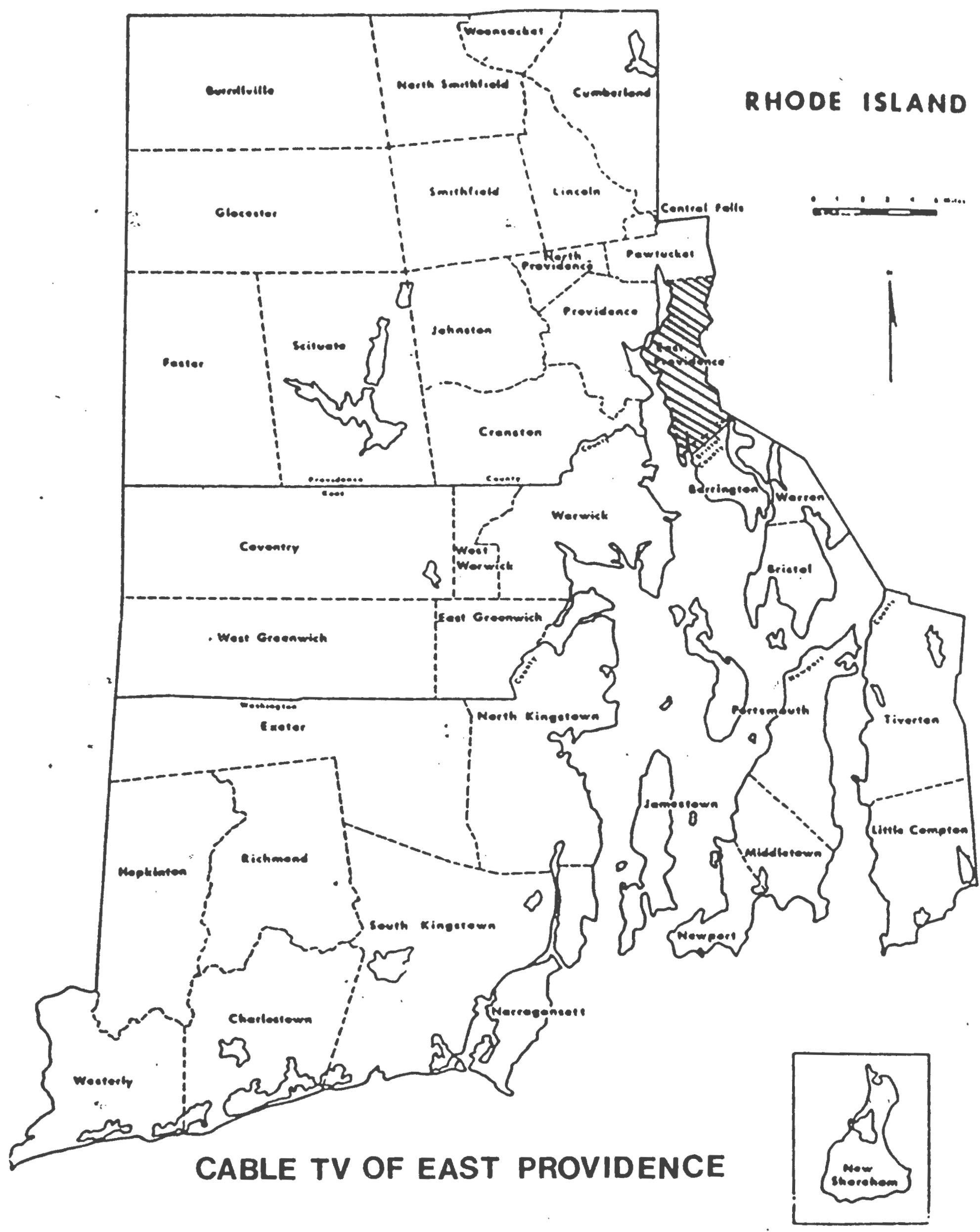


EAST PROVIDENCE

Cable TV of East Providence

East Providence, Rhode Island

Cable TV of East Providence offers a seven phase training program. A text book is usea in conjunction with the classes and subjects range from camera munipulation lighting and to editing. More advanced classes may provide a one to one situation because historically the number of participants diminishes as the program progresses in difficulty.

Technical assistance is afforded quite readily. This initial concept was to teach those individuals the basics in the classes and let them go on their own. This has been refined to give aid when needed. All equipment is on a first come first serve basis, and then only when one has been checked out on the item(s) to be used.

Cable TV's airing process requires an application to air a program. Once paperwork has been completed, it should be turned in along with a descriptive copy of the program (if taped) for review. This is to ensure that all copyright and talent release requirements have been met and that each program has music. The review also provides time to determine if the program is in anyway profit oriented or too obscene to air.

A program can be aired with as little as 24 hour notice, but the company promotes a one 1 week 
notification. At this, time volume for public access is not large, but possible future demand may eliminate the 24 hour privilege. The company does not promote attempts to go head to head with the prime time programs of the major networks. Where possible, the recommended time is between the hours of 5 and 7 o'clock p.m., when interested viewers may turn away from game shows. 


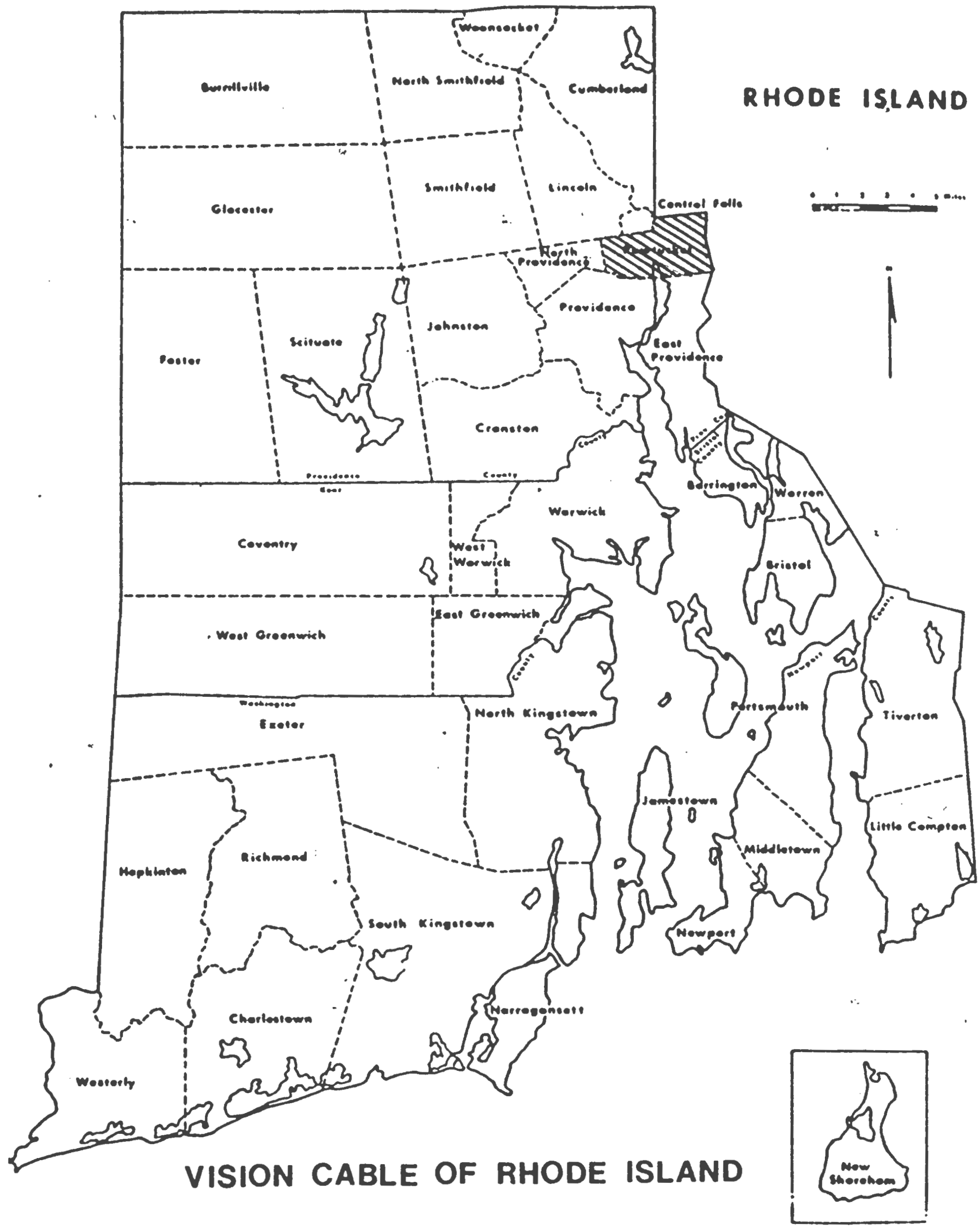


PAWTUCKET

\author{
VISION CABLE COMPANY OF RHODE ISLAND \\ PROVIDENCE, RHODE ISLAND
}

Vision Cable Company of Rhode Island provides training classes with the equipment that would be needed to produce a program. This includes cameras and editing facilities. Cable Vision Co. of R.I. stresses editing skills in their training and requires that a first production is done through completion,to ensure all areas are familiar to the individual or group. Technical assistance is provided at all stages of production.

Equipment, both in house and take out, is available for usage, but is restricted to those who have taken the classes and said equipment is available on a first come first serve basis for those individuals.

The initial steps in arranging air time would require filling out the necessary paperwork. This paperwork covers much information, including your time alternatives. While time is virtually unlimited, time slots are issued on a first come first serve basis. When filling out the paperwork, one should consider that the most concentrated demand for air time is during the hours of five o'clock and eight o'clock in the evening.

Vision Cable Co. of R.I. requires a 2 week advance notice for a production, but notes it can be flexible if necessary. They warn that notification less than the 
required 2 weeks can result in a less desirable time slot or the program may end up being aired without notice to the public and one should keep this in mind. 


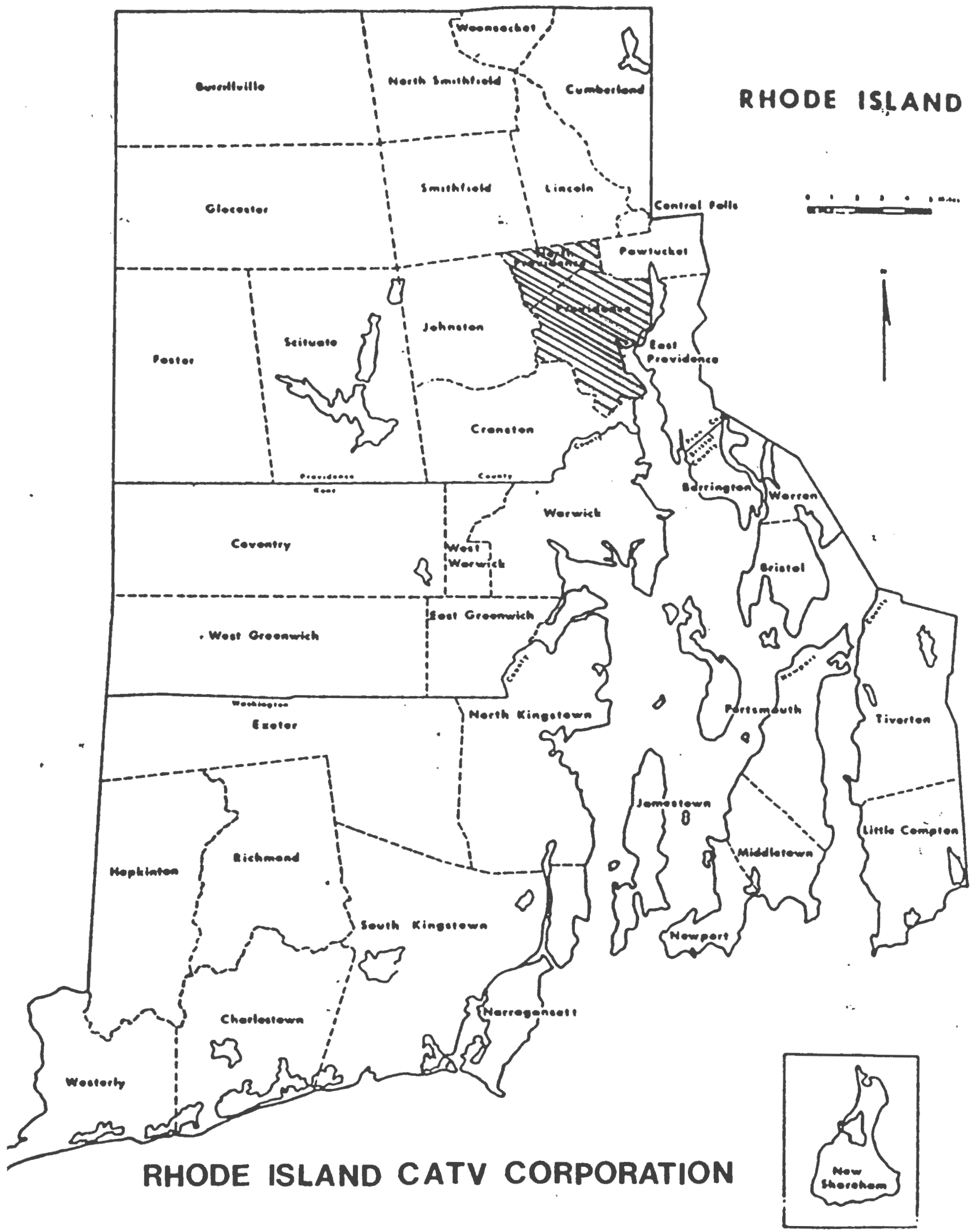




$$
\begin{aligned}
& \text { NORTH PROVIDENCE, PROVIDENCE } \\
& \text { RHODE ISLAND CATV COPORATION } \\
& \text { PROVIDENCE, RHODE ISLAND }
\end{aligned}
$$

CATV provides training programs that entail hands on experience with the equipment, both take out and studio equipment.

Techinical assistance is offered where needed, but most processes are covered in the training program.

Equipment is available on a first come first serve basis and studio use can be arranged.

Airing your program on CATV would require both, your being headquartered in the area and that you have attended the classes that are given by the cable company.

There was no mention as to what forms are required to be filled out before your program is airea. Air time is on a first come first serve basis. Time slots are not difficult to get, but the most demanded time slot is during the six o'clock p.m. to eight o'clock p.m. time frame. To get listed on the community bulletin and access calendar, notification should be given at least 3 days in advance. 


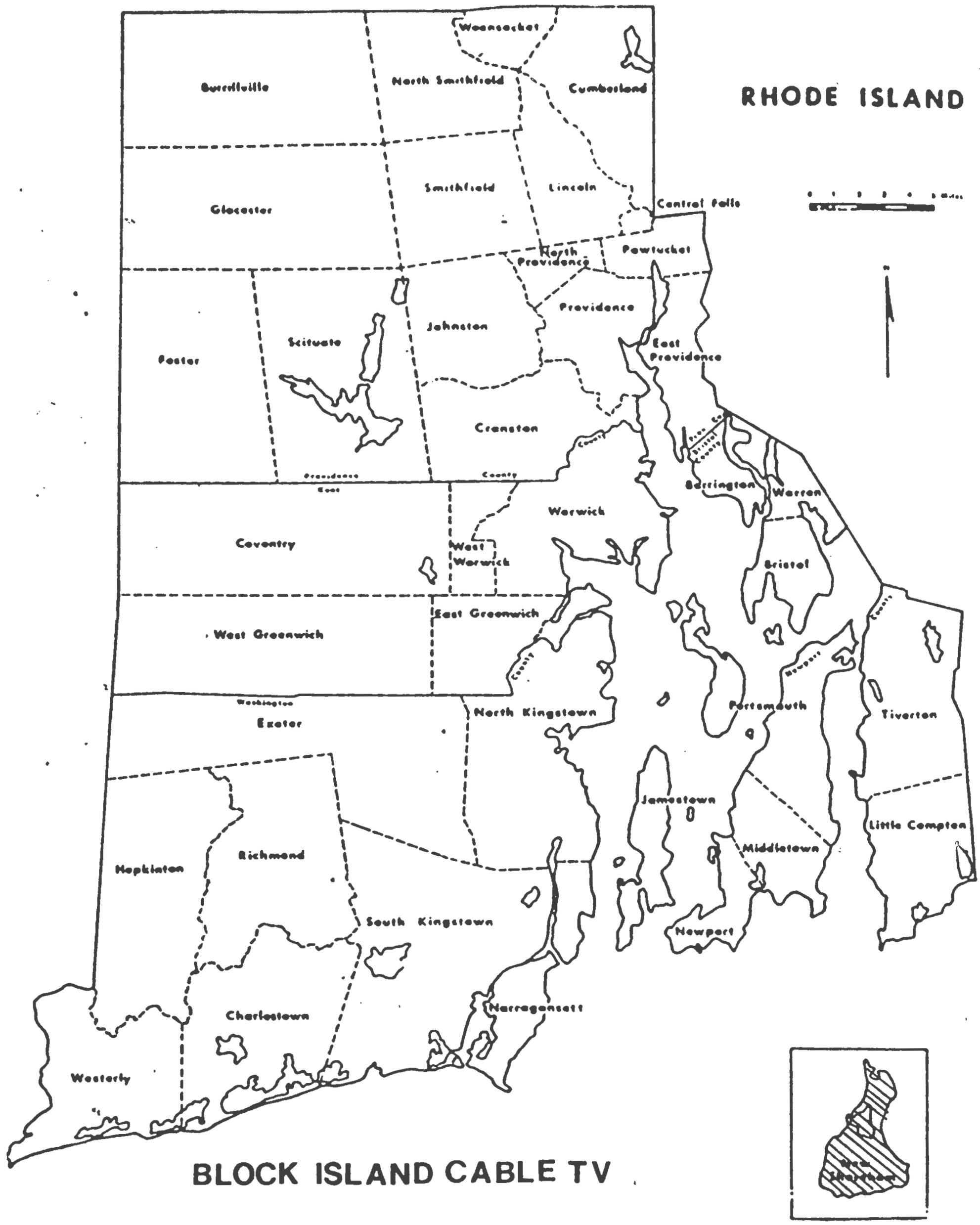




\author{
NEW SHOREHAM \\ BLOCK ISLAND CABLE TV \\ NEW SHOREHAM
}

\begin{abstract}
Block Island Cable TV is a very unique situation. since the area is small and the community is so intimate, virtually everything is done by the owners, the Bendokas. Planner should call and inquire directly as to the specific details involved relative to your project.
\end{abstract}




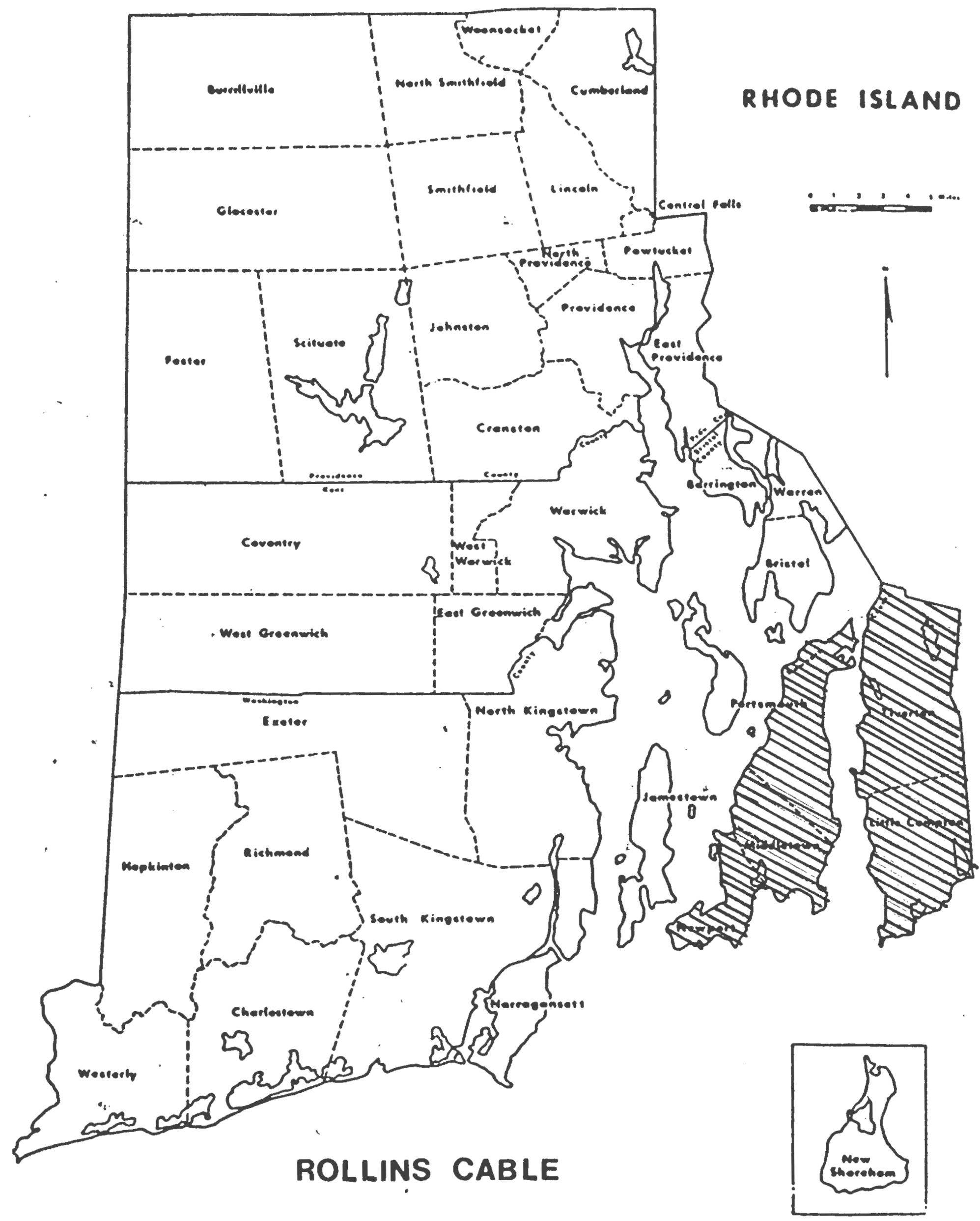




\author{
PORTSMOUTH, MIDDLETOWN, NEWPORT \\ TIVERTON, LITTLE COMPTON \\ ROLLINS CABLE \\ (BELLEVUE, NEWPORT)
}

\begin{abstract}
Rollins Cable provides a basic introductory class to familiarize the user with the camera equipment, recorder and microphones. They also give advice on trouble shooting various problems. Advance training is given on a one-toone basis. This is done for two reasons, practicality and effectiveness; many people take the first introductory lesson, but there is a high rate of attrition as the classes progress and secondly, it has been found to be more effective to provide a hands on situation when working with an individual or small group.
\end{abstract}

Al1 equipment is available after one has been checked out on it. The studio facilities can be utilized as well as the cameras and editing equipment. Equipment and facilities can be reserved but is done on a space available basis.

The public access director should be contacted at least 2 weeks before air time. The director will assist in all matters pertaining to the airing of the program, including paperwork and audio/visual quality review. If a program is of poor audio or video quality it might require reworking before being aired. 


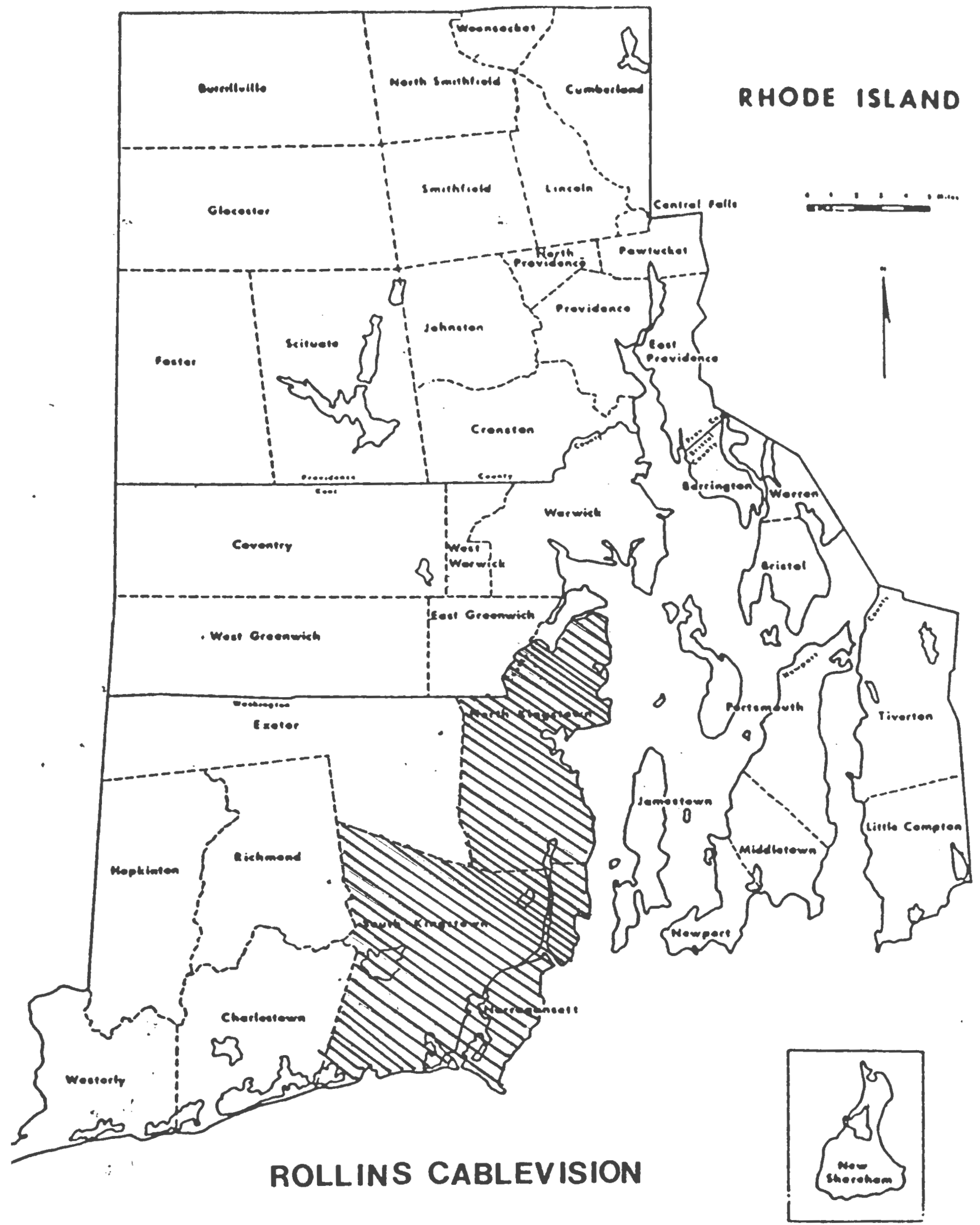




\title{
NORTH SMITHFIELD, WOONSOCKET, CUMBERLAND SMITHFIELD, LINCOLN, CENTRAL FALLS ROLLINGS CABLEVISION OF RHODE ISLAND
}

\begin{abstract}
Rollins provided a basic introductory class to familiarize the user with the camera equipment, recorder and microphones. They also give advise on trouble shooting various problems. Advance training is given on a one-toone basis. This is done for two reasons, practicality ano effectiveness; many people take the first introductory class but there is a high attrition rate as the classes progess and it has been found to be more effective to provide a hands on situation when working with an individual or small group.
\end{abstract}

All equpment is available after you have been checked out on it. The studio facilities are available and camera and editing equipment can be used; both can be reserved but is done on a space available basis.

The public access director should be contacted 2 weeks before air time. The director will assist in all matters pertaining to the airing of the program, including the completion of the necessary paperwork and audio/video quality review. If the audio/visual quality of the program is poor, reworking the program may be required before it is allowed on the air. 


\section{RESPONSE OF PLANNERS TO QUESTIONAIRE}

Just as with the cable companies population parameters were compiled from figures obtained by surveying the planners. The first question asked "Approximately how many people attend planning issue meetings in your community?" the second question asked " what is the population of your community?". These two questions were asked in an attempt to gain insight in to what percent of the population actually comes to meetings airing planning issues. The results were startling. Of the 652,219 residence of the study area only an average of 19 people actually attend planning meetings. In other words less than $1 / 2$ of 18 of the population attends meetings.

In surveying the planners it was discovered that while 75 percent knew which company serviced their area, only 318 had considered using the service and of those, only 4 had actually aired programming ( 3 aired a meeting and 1 presented an educational planning series).

If cable is so strong a medium, why isn't there more participation by planners? When asked why they had not utilized public access, 44.4 percent indicated the lack of familiarity with the program and what its relation to planning could offer. With 338 responding that staff and budget constraints, if not outright reductions in the same, made the venture at this time prohibitive. Those planners who had actually 
taken classes in public access represented 22.28 of the responses, but none had persued any further than the initial class. The remaining $21 \%$ were investigating the public access system in their area and while they have not as of yet used cable, they are considering it for the future.

Where most indicated their reason for not using cable, was the lack of knowledge relative to the capabilities of public access, visualizing its potential might be difficult. But that is exactly what planners were asked to do in question 9 which asks, "Would you use cable in the future?" The vast majority 698 answered in the affirmative, of this majority 788 stated enthusiastically an unconditional yes. Only 238 flatly rejected the posssibility of using public access as a planning tool.

There was a degree of hesitaiion the part of some planners mainly because their present planning operations are part-time and there are no indications of full time activity in the near future.

What of those planners who have taken advantage of cable? Before being able to commit to the "potential" use in the future it is essential to evaluate the present. of the responding communities 4 have used the public access to reach their community on planning issues. Of these, only 1 has used the system more extensively than airing meetings. What was presented by this community was a program aired in conjunction with review of the water plan. The response to these programs have been mixed, some 
viewers expressed outright boredom. While other programs gained instant fame. One repondent states of such a program, "I was constantly stopped by people and we've been reairing a certain program a number of times." This response was from a planner who appeared on a talk show format program.

Would these planners utilize public access again, $100 \%$ responded with an enthusiastic, yes! As a matter of fact, all stated that they would expand their programming to go beyond the meetings to include educational type presentations before an issue comes to a meeting to let people know what the options to these issues are before the proposal is accepted or rejected.

Regardless of how limitless a potential or powerful a medium cable may be, unless the participants are willing to harness that potential and channel the power to perpetuate the planning process, it will amount to nothing more than a squandered resource.

Station representatives expressed their "Belief" in public access and their "Encouragement" in its use. But what of the planning community? Their opinions and comments were sought as to cable being an effective way to implement planning strategies, introducing goals and policy and as a public forum. (question 10)

All but one of the respondents felt that cable can be an effective planning tool. The concensus was that cable would be more helpful then newsprint, in that "It would 
give a three dimensional explanation rather than a reporter's perception. Planners contend that, "This would give the ability to get more depth on a subject than can be presented in the newspaper and it would be more dynamic." It should be noted, that all the planners polled use the newspaper in their community as virtually the sole means for informing their community.

Some planners pointed to situations where fears are generated by printed commentaries. An actual dialogue between proponents of various opinions may instigate some of this. "It would allow you to explain a subject more indepth,and alleviate fears of a project." "It's a good way to get across what is actually being proposed."

There were two qualifications expressed. The first was that the medium doesn't, as yet, have the creditability it needs since the viewing audience presently considers it a novelty. The second qualification was that cable may take away from the personal touch and that it might best be reserved strictly for state wide issues.

What planning issues could best be served by public access? This was expressed in question 11. Almost all the respondents referred to "major planning issues" or topics that would take "time" to explain. The three elements that were overwhelmingly embraced were zoning issues, master plan topics and development proposals. All referred to the educational approach through cable so that the residents of their community could make an "informed" decision. 
The next most common response was to use the cable medium to inform the community as to "what planning is about" and why it is needed.

The underlying theme was to get more quality information to people and to avoid uninformed opposition or approval of issues.

\section{CONCLUSIONS AND RECOMMENDATIONS}

\section{FINDINGS}

Several important points have been established by this research. Specifically, it indicated that all parties recognize the potential for public access and the mechanism for reaching that potential.

The public access law actively encourages the use of public access as a medium for public expression. In doing so, time must be made available to all users without discrimination and free of charge. Professional, technical assistance must be provided at the companies expense for planning, production, and equipment use.

The companies have embraced the concept of public access and are committed to it beyond the letter of the law. The cooperation and assistance offered is for the program organizer's benefit.

While a majority of the planners have not as yet taken advantage of public access, they see its future 
impact as a way of making the planning process more relevant to the public.

Will the public watch? According to the Michigan state study cited earlier not only is the public watching, but more then half of the cable subscribers watch on a regualar basis.

RECOMMENDATIONS

This research was undertaken to study the use of public access television by planners, and therefore, it would only be appropriate to recommend to the planner aids that may assist in the production of a program.

The first step is to write the concept of your program idea. The concept is simply a brief discription outlining the general theme of a program. Its length is not important but it should address such areas as: the type of program to be produced, what facilities are to be used and the length of the program.

The concept should also reveal the subject matter, who will appear, what they will do and discuss, and how the show is different from others dealing with the same subject matter.

Visualization of the concept requires a story board. A story board resembles a cartoon and places the video and audio in sequence. It should also indicate changes in screens, voice overs, film clips and musical accompaniment. 
A simple stick figure arrangement would be sufficient.

Visual awareness is important. Basically, it requires you to see your production done even at the concept stage. Draw on movies that you have seen for technique, camera angles, and timing. Try to make your production interesting, but don't arown it out with changes.

In writing your script, the six basic questions of journalism also apply to television. Ask: who, what, where, when, why and how. Always ask, "If I were the audience, what would I want to know about this subject?n.

After you have established the format of your program and arranged for what ever guest may be required, be certain that a talent release form has been secured for each and every person appearing, a sample may be found on page 54 .

Music adds to the mood and can enhance a production. 24

Before using any piece contact ASCAP to apprise yourself of the music's status and ask permission to use said music. If you do not you may be subjecting yourself to rigid penalties.

Dress and looks, how important are they? After all people are going to be watching you. Wear what you are normally viewed in and feel most comfortable wearing,but look smart. 
TALENT RELEASE FORM

(Sample)

I hereby consent to the use of my name, likeness, pictures and/or voice by the personnel of and

(Name of cable station)

(Company, if program

is for industry use)

for cablecasting, direct exhibition and subsidiary purposes.

Such uses will not be made as a direct endorsement by me of any product or service. I hereby indemnify you and your licensees respecting any claim or action agdinst you, your licensees or the executives and personnel, arising from my actions or statements on the program.

Signed

Address

Date

I decree that $I$ ain the parent (or guardian) of who is a minor and that I hereby authorize, approve and agree to the contract signed by him/her as stated above.

Signed

Address

Date

Witness

4 


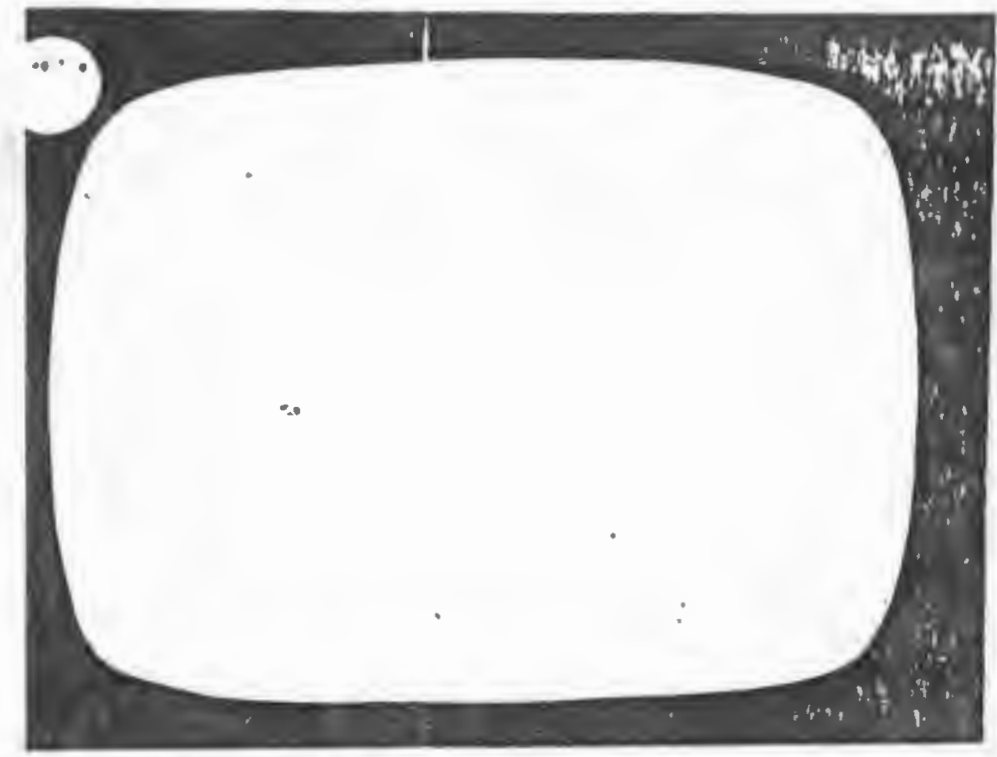

mera direction

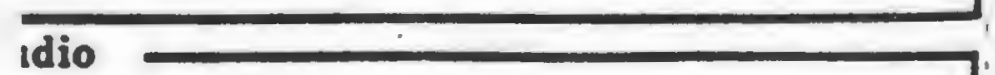

Idio

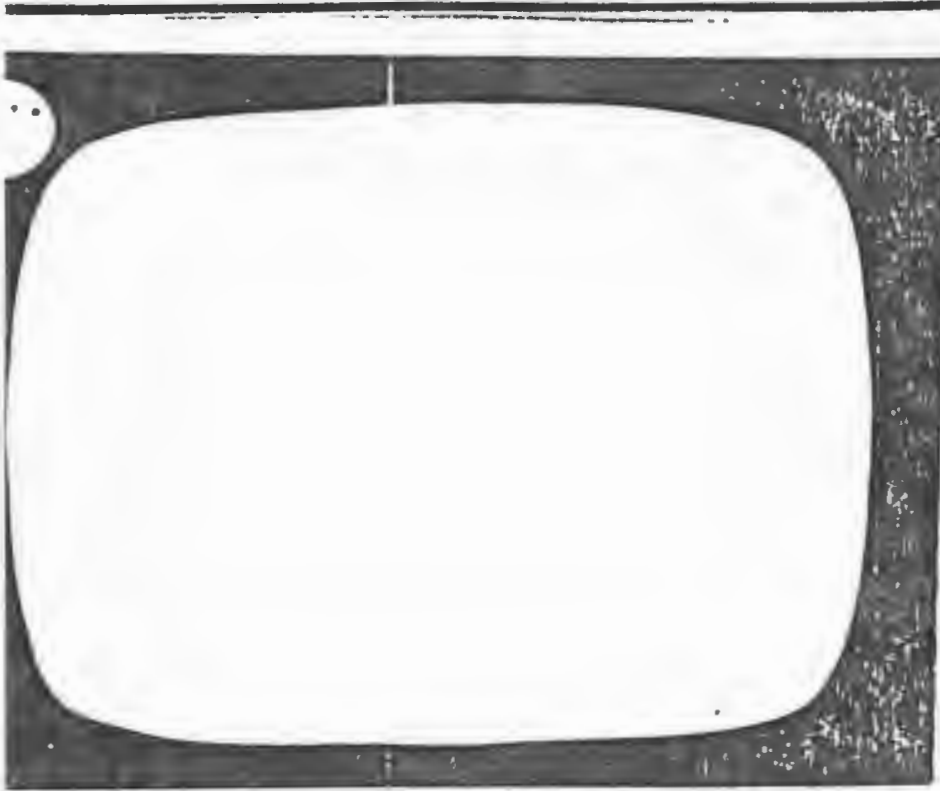

nera direction.

\%

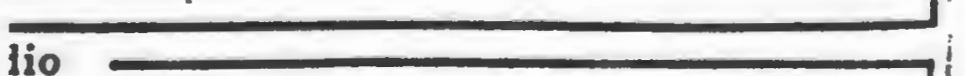

lio

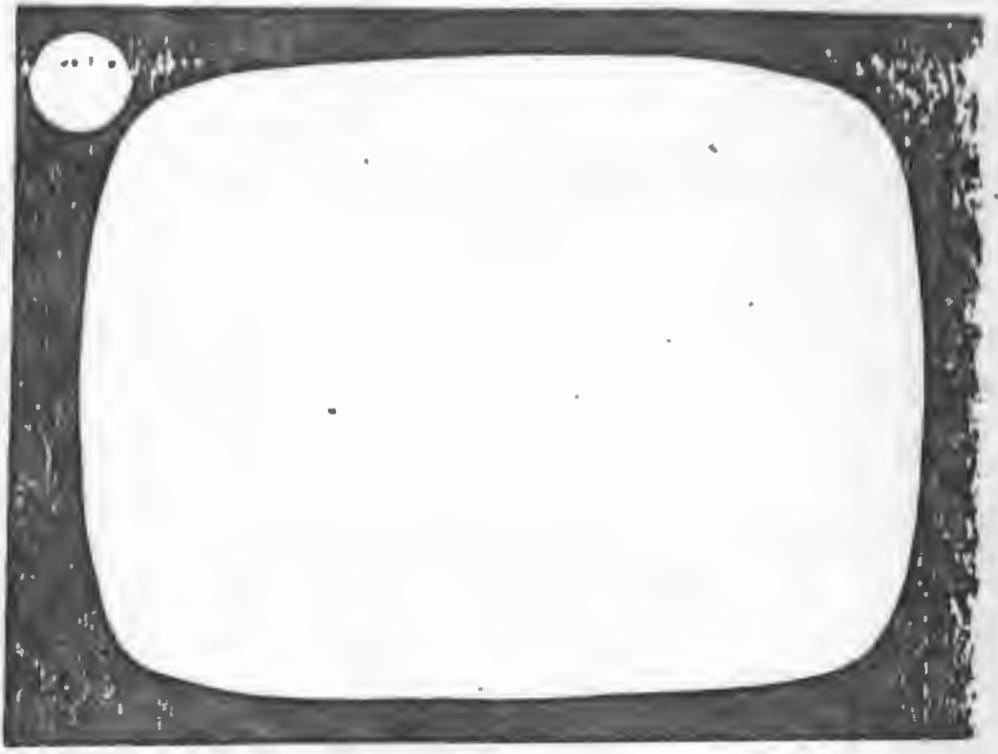

camera direction

audio

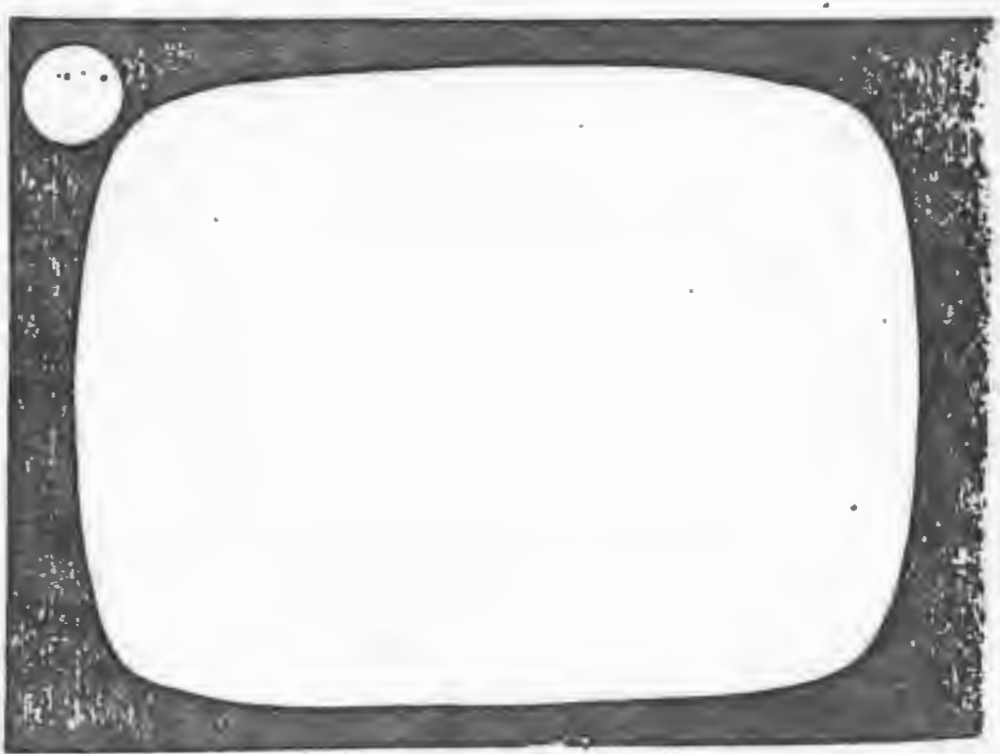

camera direction

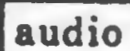


There are some things to look out for, they are as follows:

1. Do not wear stripes or plaids, especially narrow ones, they have a stroboscopic effect and appear to be moving.

\section{Equally disconcerting is flashy jewlery.}

3. Avoid clashing and loud colors (especially red). Color is easily distorted on television and do injustice to your actual appearance.

4. Black and off-white are acceptable, but may appear rather drab on screen. Never wear solid black or white as they tend to make one look grotesque.

Always check your appearance before you go on camera, as a hair out of place or other imperfection may distract your audience's attention.

\section{CONCLUSION}

Public access cable has been a reality in this state for nearly 10 years. It is free of charge and time is abundant. Yet, it has been virtually ignored by the planning profession. Michael Bland stated, "So far, television simply uses us. Yet like all other things it is there to be used by us. It is nothing more than a communication medium which is always searching for entertaining material. Almost anybody can use it to get a 26 message into millions of homes-FREE." 
The significance is that an area that directly effects each and every citizen, the planning of their community is predominantly without their participation. Many citizens are not aware of the strategies proposed for their community or the ramifications of implementation. By utilizing public access cable, planners can successfully educate their communities. People are generally interested in what happens in their community but find it difficult to come out to a meeting after a day at work. Cable follows a path of least resistance. The planner brings his/her message in to the residence living room.

Television is like a tiger, its great to look at but people are terrified to go near it. Most people presume that producing a show is only for professionals. The reality of the matter is that anyone can do it with training and time.

By sending staff members to the training programs offered by the cable company, an in house production company can be developed. It has become accepted practice to send staffs to be trained on computers and word processors, why not cameras and editing machines?

Public access is not meant as a substitute for personal contact with the community, nor is it a short cut method to planning. What it is, is an emerging tool that can provide the planner with an additional means of reaching the people he/she serves. 


\section{APPENDIX I}


NAME OF COMPANY;

CONTACT PERSON;

1. What is the number of house holds you now service?

2. What is the approximate household potential audiance?

3. What is your companies policy in reference to public access cable?

4. What kind of technical assistance do you offer? (classes, equipment, ect)

5. How would a planner get a production aired? 
6. What are the most common miss conceptions that are made in reference to public access?

7. What kind of notice should be given your company before airtime?

8. What time slots are available for public access.

9. What would a planner need to know in order to successfully air a program? 
10. Are there limitations as to what can be aired?

11. Are there companies that do productions of this nature that a planner can contact?

12. Have any towns taken advantage of this service?

13. Comments 
APPENDIX II 
NAME OF TOWN;

CONTACT PERSON;

POSITION:

1. Approximately how many people attend planning issues meetings in your community?

2. What is the population of your community?

3. Do you know what cable company servises youc community?

If yes which one?

4. Has your community considered using public access to air planning issues? (if no go to 9)

5. What issue did you air?

6. What was the response? 
7. Would you utilize cable again? Why or why not?

8. Why did you not? (cost, expertise, did not know about the service,etc.)

9. Would you utilize public access cable in the future? Why or why not?

10. Can cable be an effective way to implement planning strategies, introducing goals, and policy, as a public forum?

11. What areas of planning could best be served by public access? 
12. What medium do you use to reach your community?

12. Comments or opinions? 
1 Public Law 98-549; p.2.

2 IBID.

3 Public law $98-549 ;$ p.4.

4 IBID.

5 IBID.

6. Burke, Ed, Rules Governing Community Antenna Television Systems; (State of Rhode Island and Providence Plantation Public Utilities Commision Division of Public Utilities and Carriers, Jan. 30, 1981 Revised to Jan. 14, 1984 ) p.1.

7 IBID.

8 IBID.

Systems; p.3.

9 Rules Governing Community Antenna Television

10 IBID.

11 IBID., p.15.

12 IBID.,P. 46 .

13 IBID., P. 47.

14 IBID.,P.48.

15 IBID., p. 49 .

16 IBID.

17 IBID.p. 51 .

18 IBID.

19 IBID.p.52.

20 IBID.

21 IBID.

22 Buske, Sue Miller, Accepting Alternatives to Broadcast Quality; (Video User, Feb. 1983). 


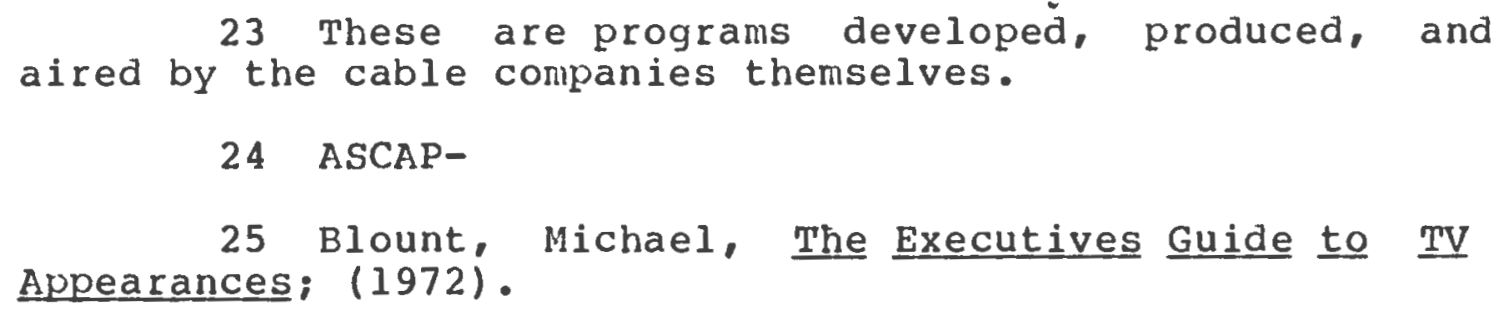




\section{BIBLIOGRAPHY}

Altshuler, Alan, "The Goals of Comprehensive Planning," $\underline{A}$ Reader in Planning Theory, Oxford: Pergamon Press, 1976 .

Blount, Michael, The Executives Guide to TV and Radio Appearances, White Plains, N.Y.: Knowledge Industry Publications, Inc.,1979.

Bolen, Richard, S." "Social Planning and Policy Development," The Practice of Local Government Planning, Wash., DC.

Buske, Sue, Miller, "Accepting Alternatives to Broadcast Quality," Video User, Feb. 1983.

Cafferty, Pastora San Juan, "Planning for Diverse Human Needs," The Practice of Local Government Planning, Wash.,

DC.: International City Management Association, 1975.

Census of Population and Housing, Summary Tape File, 1980.

Docket No. 1548, "Adoption of $\frac{\text { Rules Governing Corimunity }}{\text { (CATV) }}$ January $\frac{\text { Antenna }}{30,1981}$.

Docket No. 1548, October 16, 1981.

How to Make Cable TV Work For You,Wauconda, IL.: Spectragraphics, 1982 .

Lucchesi, Erid, and Gil, Efraim, Citzen participation in Planning.

Public Law 98-549, 1984.

Rules Governing Community Antenna Television Systens, State of Rhode Island and Providence Plantations Public Utilites Commision Division of Public Utilities and Carriers, 1981/1983.

Williamson, Frederick C, Directory of City-Towns Officials, 1981 . 